\title{
The Concept of Folklore: An Overview of the Psychoanalytic Reading of Folklores
}

\author{
Farhain Khan
}

\author{
Research Scholar, Patna University, India
}

Stories have always found a special place in every society and a story teller has had listeners hung on to his or her every word breathlessly for ages. These stories were of myriad quality ranging from comic to heroic, from fables featuring animal as anthropomorphic to fantasy with goblins and fairies. The term folk lore or folk tale is used in English to refer to fairy tales in English such as Cinderella or snow White,Folk Tales in the broader sense of the term includes all forms of prose narrative, written or oral which are handed down through generations. The modern story telling differs from the traditional folk tale in one important aspect. The modern storyteller emphasizes on the orig inality of the material. Whereas the teller of the folk tale prides on the fact that he or she can pass down the folklores almost verbatim. The folk teller can also uses their own embellishment in the tale in order to mesmerize their audience .It is therefore difficult to separate the oral from the written in folk tale because it travels mostly orally and no folk tale can be traced back to any one writer. Which is to say that maybe the oral stories need not have been always oral. But once the story teller or the raconteur recites it in the public, it becomes more of something to tell to the listener and not something to be read. Historically these public spaces where raconteur and poets recited the popular tales, been the major source of entertain ment for the general public. Ancient Greek performed popular plays for the public and there was a stress on the oral recitation and the concept of catharsis or the purgation of the feelings of pity and fear. This art of story telling is not bound by any segment of the society or civilization but is ubiquitously present . It is older than history itself and it travels orally through continents and through space and time. It may differ from place to place but it exists to fulfill one social function and an important human need, which is entertainment. There also exist a curiosity about history or the legends. The oral recitation of heroic tales and legends lend an almost pride like quality among the listeners. The legends of the heros are mostly about their tribes or society and they represent the ideals of honour, pride and virtue for the entire tribe. India as a diverse and culturally rich county has written literature going thousands of years back before Homer
Folklore as a new field of learning emerged, relatively new in the nineteenth century when the scholars both in England and Germany began to observe closely at the cultural ways of the lower classes. The Grimm brothers began publishing volumes of oral folk narratives and the interpretation of German mythology. The term initially used for this field was 'Popular antiquity', which later proved to be too cumbersome to use and at the suggestion of William John Thomas the term "Folk-lore" was adopted in 1846. The term folklore in the present time has come to be a whole field of learning, research and subject matter of the field. The field of folklore or folklife studies constitutes firstly and primarily of oral literature also knows as verbal art or expressive literature. This stands for those oral literature either spoken or sung or voiced forms of traditional utterances showing a repetitive pattern. The folksongs or folktales circulate by worth of mouth and without any authorship. Unlike the author and their printed works (since the printed literature was born), folktalesdoes not boast of any particular copyright. One of the glaring examples is of the recitation of Ramayana, a mythological folktale that dominates the cultural as well as the religious sensibilities of the Indian subcontinent. The narration of Ramayana is carried mostly through oral recitations and carries a gamut of proverbs and various aspects of folk and cultural behavior. Now Ramayana also seems to embrace the local and the cultural aspect of the region that it is orally transmitted to. Ravana, the king of Lanka who abducts Sita, wife of the protagonist Ram is celebrated and worshipped in present Sri lanka and by the Betul tribals in Madya Pradesh in India .But elsewhere, Ravana is burned in a symbolic gesture of the defeat of evil in the rest of the country.

Coming back to the research and scholarship aspect of this field, there are many current theories of folktale namely Historical-geographic, Ideological, Functional, Psychoanalytical, structural, Cross cultural, Contextual etc. The scholars of folk lore attempts to study the similarity among the folk tales of the world and also to understand the nuances of the oral tradition. To a scholar of folk tale the problems of interpreting and studying Folk tales present its own different challenges. There is problem of understanding the origin of the folk tale 
followed by deciphering if the folk tale have any hidden significance or not. The folk lorist also wrestle with the issue of dissemination and the variations of the folk tales which are present around the world. they strive to understand the historical occurrence of this dissemination. In this paper we are going to delve deeper and probe the psychoanalytic theory of folklore. It has been considered as the most speculative of all the theories mentioned and was not seen very kindly by the orthodox or traditionalist Folklorist. The nineteenth century reading of Folk tales resulted in glorifying the history for the sake of national glory / greatness or glorifying the deeds of national heroes. In its budding form it was a new field of imaginative research and a form of national pride. But soon it took on a extreme form dovetailing with aggressive nationalism and virulent political ideology as seen in Nazi Germany and Soviet Russia in the $20^{\text {th }}$ century.

The Psychoanalytic theory replaced the symbols of divinity and heavenly phenomenon with sexual symbolis $\mathrm{m}$. The Psychoanalytic theory had been proposed by Dr Sigmund Freud at the turn of the $20^{\text {th }}$ century. From Totem to Taboo (1913-14) to Future of an Illusions (1927) and Civilizations and its Discontents (1930) Freud sought to trace the complex and contradictory relationship that an individual has with the social forces and how those forces shape his/ her desire and psyche. Sigmund Freud depended heavily on myths, taboos, fairytales to support his theory and his research into the subconscious mind. In the "Interpretation of Dreams"(1900) he presented his thesis that dreams of an individual represent or express the latent repressed wishes and fears of infantile sexuality in symbolic gestures. Then the dreams were equated with myths and other kinds of folklore and were subjected to similar interpretation. If the dreams represented the repressed infantile desire of an individuals , then myths holistically represented the repressed psyche of the childhood of the race. In the $19^{\text {th }}$ century the myths and folktale exhibited the heavenly battle between the sun and night, light and darkness, thunderstorm and morning light. With the advent of the Psychoanalytical theory, the myths were now a striving between the male and the female. The hero-Achilles, Perseus, Theseusrepresented the phallus and the enveloping light stood for the wo mb. Thus in the Freudian terms the male genital was symbolized by sticks, tress, umbrellas, pencils, hammers, umbrellas etc. The female genital is represented in the same manner by caves, bottles, boxes, doors, gardens, flowers etc. The dreams or fairytales about dancing, riding, climbing, flying signified sexual gratification. Interestingly hairfalling off symbolized castration.
In the myth of Oedipus, Freud illustrated his psychoanalytical theory. The myth according to Freud exposes the dark repressed desire of incest and dreams of slaying his father. Oedipus is a Greek tragic hero and the legend of Oedipus is a tragic one, where he slays, unknowingly his own father and marries his birth mother. On being a ware of the truth he blinds himself out of sheer shock and grief. To quote Richard M.Dorson " in the myth of Oedipus, Freud found a superlative illustration of mythical narrative that exposes the dark suppressed desires and drives of the children grown to adults. The boy-child loves his mother incestuously and dreams of slaying his father, in Oedipus Rex, his dreams are grievously fulfilled."

After Freud, many of his followers continued the process of enriching communication or relation between folklore and psycho-analysis.Ernest jones (1879-1959) wrote an extensive treatise on folk beliefs. "On The Nightmare"(1959), which dealt with the figures of medieval demon, vampires, werewolves, incubus etc. In this terrain of monster which are the stuff of nightmare, jones perceived a direct relationship between the infantile fantasies and folk lore. The figure of witch according to jones is an exterio zation of a wo man about herself and her mother and a witches' sexual relation with the Devil was supposedly about a women's incestuous fantasy. in the similar vein the trope of vampire and its blood sucking activities point to a repressed oral sadism . "The devil, whose phallic symbolism is evident in his frequent identification with a snake, is a father figure incarnating two repressed wishes, the desiers of the son to both imitate and defy his father." aCCORDING TO jones repressed incestuous emotions were tied up with these belief and were a result of the Oedipus complex. The strict patriarchal and ascetic influence of the Church helped to foster there repressed emotions associated with these folk lore.

German born author and lecturer Erich Fomm adds his own dimension to the traditional odeipus complex as illustrated by Freud. In his primer published in 1934 called the "The forgotten language", he points out at the universal symbolis $m$ in the mythical relations and the figures of folklore. He brings the Oedipus complex to a full circle by suggesting that the myth dramas are actually a struggle between the patriarchal domination of the Creon (Ruler of Thebes in the legend of Oedipus) and the Matriarchal order represented by Antigone (daughter of Oedipus and his mother Jocasta) and supported by Oedipus, who consumed by grief and subsequently dies in the grove dedicated to Goddess Furies. Applying his reading to the fable of Red Riding hood, where the Freudian reading was of a maiden straying fro $m$ the path of virtue and being seduced by the wolf symbolizing the 
man as the red cap is the menstrual symbol. Fromm reads the story different, where the wolf displays a pregnancy envy when he fills his stomach or wo mb with the girl and the grandmother and is punished when the Red riding Hood stows stones which is a symbol of sterility in his insides. The tale is presented as a tussle between a man and a woman who hates men and also abhors sex.

C.S Jung, after severing his professional relationship with Freud established his own school of analytical psychology in Switzerland. He and his followers rejected the name and the sexual symbolism of the psychoanalysis. But from the view of the folklore both have a lot in common. Firstlyfolklore forms an important part of their discipline. Secondly both interpret folklore and fairy tales with the help of symbolism, If Freud pairs the opposite like malefemale, phallus-vagina, in clear sexual terms Jungs uses theterms consciousness-unconsciousness, Life-Death, God-Satan. What is common between them is the use of consciousness, which is the key concept in their interpretation. Jung uses the term collective consciousness as opposed to the personal consciousness used by Freud. And by this term he had something deeper in mind. According to Jung all men shared in the collective consciousness whose content he termed as archetypes. These archetypal dreams emerged from the central or master mold of the collective unconsciousness and sometimes becomes a part of the personal unconsciousness. These archetype represented a form rather than content.

One sees this relationship in the dual nature of the mythological figure like the Greek Gods who were both helpful and spiteful at the same time. Jung frequently employed folklore in his writings. In one of his last work he wrote on a modern phenomenon which has folkloric implications, Unidentified Fly ing Objects. He explained these sightings through the deep seated anxieties of the people of the earth who want to transcend their earthly boundaries or rather escape from it. One of the other important essays Jung had written is on the figure of the trickster in the essay " The trickster, a Study in the American Indian Mythology"(1956). According to Jung a trickster is a a God, animal and man at the same time, vested with superhuman powers and is simultaneously divine, bestial and superhuman.

Psychoanalytic analysis involves the interpretation of the symbols in the tales to reflect the collective consciousness of the people. This interpretation studies a cultural folk tale to interpret the psyche of its people. Psychoanalysis offers deeper insight into the cultural and psychological aspect of the folk lore as it attempts to decipher the symbolic meaning inherent in the folk tales. This approach not only helps to understand the tales but also the people by applying the concept of sexuality, power and gender relations. The knowledge and learning of people can be deciphered through the process of psychoanalysis where one can understand the hopes, aspiration and the psychological makeup of the people. Folk tales are the products of the human imagination, creativity and also reflects the unconscious needs of the society. Primarily among the $m$ is the wish fulfillment and the folk tales reflects this unconscious need. Folk tales such as Cinderella or Hansel and Gretel demonstrates the overcoming of goodness over persistent wickedness. In India the panchtantra tales or the Jakarta tales are avidly read and recited by all sections of the society. These Panchtantra tales has the animal as the lead characters and the tales always has a moral lesson at the heart of the it. The legend about Panchtantra dates back to Ancient India where a King appointed a teacher Vishnu Sharma to educate his indifferent and lazy sons. In order to pique their interest in learning, he crafted these tales with a strong moral lesson at the end of each tale. The Monkey and the Crocodile tale could glean several lessons from the stories such choosing one's companion carefully as demonstrated. Each tale has a lesson that builds up a strong individual, which in turns contributes to the building up of the community. The psychoanalytic reading of the folk tale helps to understand the collective consciousness of the society and ultimately helps in the understanding of the human problems and builds a better social understanding.

\section{REFERENCES}

[1] Alan Dundes, 1975. Analytical essays in Folklore (Mouton Publishers: The Hague, 1975)

[2] Alan Dundes, Interpreting Folklore ( Indiana University Press Bloomington, 1980)

[3] S. Freud, The Complete Introductory Lectures on Psychoanalysis (ed. by James Strachey Alden Press: Oxford, 1971)

[4] S. Thompson, The Folktale (The Dryden Press: New York, 1952)

[5] S. Thompson, "Folktale", In Standard Dictionary of Folklore, Mythology and Legend. ed. by Maria Leach Vol. 1 ( Funk and Wagnalls Company: New York, 1949) 